\title{
Um padre e a revolução: uma conversa com o século $X X$
}

\section{A priest and the revolution: a conversation with the twentieth century}

Diego Pacheco* e Tiago João José Alves*

Um padre e a Revolução: uma conversa com o século XX11.

Muitas vezes quis acreditar que no final dos tempos justiça se faria a todos aqueles que amaram os seus irmãos a ponto de darem por eles suas vidas. Mas esse é um privilégio dos crentes. Eu mesmo prefiro ficar com uma história que um dia, sendo eu ainda menino, ensinou-me um velho lutador das causas do povo. Para lá do imaginário das pessoas e para lá de tudo o que as crenças ensinam, existe uma constelação, que os astrônomos não conhecem nem identificam (a constelação da Utopia) onde todos aqueles que lutam toda a sua vida por um mundo só de irmãos se transformam em estrelas quando partem da terra, cumprida a sua missão. ${ }^{2}$

\footnotetext{
* Doutorando em História - Universidade Federal de Santa Catarina, Florianópolis, Brasil, autor do livro: Os Times do Povo: Os grupos dos onze em Santa Catarina. E-mail: diegopacheco. hst@gmail.com

** Doutor em História pela Universidade Federal de Santa Catarina, Florianópolis, Brasil E-mail: tiagojjalves@gmail.com
} 
Assim, Alípio de Freitas lembrava seu companheiro de lutas Paulo Wright e assim iniciamos uma de suas últimas entrevistas realizada exatamente um ano antes de seu falecimento (pode ser que tenha sido a última...).

Nascido em Vinhais, Bragança em 1929, foi ordenado padre em 1952 passando a trabalhar diretamente com comunidades carentes na Serra do Montesinho. Cinco anos depois, aceitou o convite do arcebispo do Maranhão e dedicou-se a atividade pastoral no Brasil. Passou a celebrar missas em português, antecipando as orientações do Concílio Vaticano II, construiu escolas e unidades de atendimento a saúde nos subúrbios de São Luis. Em 1962 estava no Congresso Mundial da Paz em Moscou, onde teve contato direto com Pablo Neruda e Nikita Kruchtchev. Voltando ao Brasil, rompeu com a hierarquia da Igreja e empenhou-se na candidatura de Miguel Arraes ao governo de Pernambuco. Nas andanças pelo Brasil, passou pelas favelas cariocas e pelas prisões políticas antes mesmo da ditadura. No movimento camponês conheceu Francisco Julião e junto com ele fundou as Ligas Camponesas. Em Santa Catarina, palestrou em diversas cidades nos meses que antecederam o Golpe Civil e Militar de 1964, onde, junto com o deputado Paulo Stuart Wright e a Frente de Mobilização Popular, difundiu a necessidade das reformas estruturais do Estado brasileiro.

Após o golpe, exilou-se no México e recebeu treinamento militar em Cuba. Em 1966 retornou clandestinamente ao Brasil e passou a defender o uso da guerrilha armada contra o regime. Preso em 1970 sofreu choques elétricos, tortura do sono e afogamentos. Da prisão escreveu uma carta denuncia sobre a situação brasileira. A carta, publicada em grandes jornais portugueses, provocou desconforto diplomático entre os países e Alípio de Freitas acabou libertado em 1979 como apátrida.

Na década de 1980 passou a viver em Moçambique realizando atividades com movimentos campesinos e só retornou a sua terra natal em 1994 passando a trabalhar na RTP e atuando em diversos movimentos sociais. Fundador do Partido Revolucionário dos Trabalhadores no Brasil foi um dos fundadores do Bloco de Esquerda de Portugal em 1999, assim como o fundador da Casa do Brasil de Lisboa.

A conversa com o "Padre do Povo" ocorreu em seu apartamento, cerca de vinte minutos do centro de Lisboa. Nessa entrevista conhecemos um indivíduo simples, conhecedor de sua importância histórica e de seu vanguardismo progressista nas fileiras eclesiásticas, e, apesar de abatido fisicamente pela avançada idade e o acúmulo de lutas (e agressões), ainda empenhado em mudar o mundo e lutar contra a injustiça social. Alípio fez parte de uma geração de homens e mulheres que, na tentativa de elaborar e construir um mundo socialmente mais justo, ajudou a derrubar os muros de regimes autoritários que sufocavam as mais diversas vozes dissidentes. Sua trajetória confunde-se com a história da segunda metade do século XX. Com 
essa entrevista, navegando pelas fronteiras entre memória, história, lembranças, projetos políticos, derrotas e desilusões, procuramos discutir a história recente da república brasileira e portuguesa.

Cabe aqui um agradecimento especial à companheira de Alípio de Freitas, Guadalupe Portelinha, por todo acolhimento e mediação, ao pessoal da Associação José Afonso-AJA, sede Lisboa, especialmente Anália Gomes. Também queremos agradecer pelo auxílio dado por Giulia Balbão na transcrição da entrevista.

Diego Pacheco e Tiago João José Alves: Por favor, pode nos falar um pouco sobre a sua origem familiar, o começo de sua vida em Portugal, sua ida para o Brasil?

Alípio de Freitas: A minha família, como um todo, era da pequena-burguesia, os meus avós eram da pequena-burguesia rural. Já o meu pai era funcionário público, e a minha mãe, o pai dela tinha uma pequena empresa de construção civil. A minha vó, que era mulher inteligente, as filhas foram estudar o quinto ano no liceu, naquela altura, que equivalia à escola normal. Mas a minha mãe nunca foi professora, foram professores os filhotes dela, os dois. Éramos dois irmãos, fizemos escola primária, um irmão depois fez um curso industrial, e mais tarde, já depois de ter feito a tropa [ter se alistado], foi para o Brasil. Tinha um tio no Brasil, o meu pai queria que ele fosse trabalhar na profissão dele, que era nos correios, o meu pai era mecânico dos correios, mas ele não queria. Pediu que chamasse esse meu tio que estava no Brasil, e mais ou menos discretamente, foi para o Brasil. Discretamente no sentido, meu pai não sabia de nada.

Eu fiquei em casa, quis seguir várias profissões. Primeiro, quis ser regente agrícola, o que garante a ser engenheiro agrônomo, aqui em Portugal. Meu pai disse: "Olha, pra ser agricultor ficas em casa", não podia ser agricultor, não fui para a escola agrária. Depois, quis ir para a marinha, como voluntário, mas o senhor em quem eu confiava em ir para a marinha me disse: "olha, meu filho deixa disso, a Marinha é uma miséria fardada, aquilo só tem brietes e botões, mais nada, o resto é tudo mentira. Procura outra vida que na marinha não vale à pena". Aí eu já estava no Seminário, então acabei sendo padre, concluindo o curso, poderia ter ido pra Roma, ou pra outra qualquer dessas, mas eu não estava muito firme nessa decisão que não era minha. A decisão era do meu pai, era do meu bispo, era dos meus parentes, que achavam que eu era um rapaz inteligente e que, portanto, devia tirar um curso, ser padre, mas tirar um curso numa universidade eclesiástica em Roma, ou em Salamanca, nesses lugares todos. Eu sempre a boicotar o assunto, no fim concedi que seria padre, mas não queria ir pra Roma, onde tinha já um protetor, que era muito amigo da família, que disse: "Vai pra Roma, lá eu sou monsenhor e faço tudo o que for possível pra te ajudar", eu achei aquilo meio esquisito. Bem, de qualquer 
maneira eu me ordenei padre e fui trabalhar numa escola de artes e ofícios, que era uma espécie de patronato para meninos, em Portugal, encarregada de meninos pobres. Fui pra lá e gostei, eu já conhecia aquela miudagem [criançada] e fiz um bom trabalho, sem gabarolice. Os meninos estudavam, todos estudavam na escola industrial, aprendendo ofícios mecânicos, outros aprendiam carpintaria, outros aprendiam tipografia, enfim, e aprendiam todos, mas todos sem nenhuma exceção, música. E teve uma coisa que eu instituí lá na escola, tinha outro padre a trabalhar comigo, aboli os castigos físicos. $\mathrm{Eu}$ tinha, nessa altura, 23 anos por aí. Aboli o castigo físico, que era muito costume, nas escolas mesmo, os professores baterem nos alunos, darem bofetadas, ou baterem com a régua, e eu abominava essa história de castigo, mas abominava fisicamente, não ia comigo isso de bater nas pessoas. Então a primeira coisa que fiz: reuni a turma toda, uns cento e tal meninos da escola, reuni outro padre que estava comendo, e disse: a partir de hoje, os castigos físicos aqui estão abolidos, ninguém bate em ninguém por motivo nenhum. $\mathrm{E}$ o padre disse-me assim: "mesmo que mereçam?", mesmo que mereçam, mas é preciso saber se eles merecem ou não merecem. Portanto, pra mim estão abolidas, ninguém dá uma bofetada em ninguém. É claro que ganhei logo toda a turma, e fui à professora, que era professora deles, e às demais professoras, e disse: [Alípio de Freitas] "olha, eu gostaria que os meus miúdos [crianças] não sofressem castigos físicos, nenhum, porque lá na casa eu aboli o castigo físico e não gostaria que na escola eles apanhassem. 'E se eles merecerem?', se eles merecerem, pense duas vezes." Uma delas era filha de um diretor de uma escola correcional, [Alípio de Freitas]: "porque você sabe muito bem que na escola que o seu pai gere, há castigos físicos e que nem sempre são justos, portanto, se houver algum problema, mande um bilhetinho para mim e eu resolvo esse assunto". Bem, nunca encostei um dedo sequer num menino, nem consenti tampouco e todo mundo aprendeu.

[Na casa] todos aprendiam música, estavam todos a solfejar: dó, ré, mi, todos aprenderam, alguns até se tornaram músicos profissionais, aprenderam música, foram para orquestras, foram para bandas do exército, da marinha, da aeronáutica, e outros foram para outras bandas por aí, todos aprenderam música, todos. Eu os encontro algumas vezes por aí, encontrava mais, aprenderam seus ofícios: carpintaria, mecânica, nisso eu era muito exigente, muito exigente. $\mathrm{O}$ sujeito que estava a estudar carpintaria, ele estudava as matérias de estudo, e levava tudo a sério, não era moleza pra ninguém. Passei lá dois anos, um dia eu me chateei com outro colega, peguei a minha trouxa e fui-me embora. Fui meembora e aí o bispo mandou me chamar e disse-me assim: "E agora?". [Alípio de Freitas] "Agora você faz aquilo que entender, porque senão faço eu o que entender, vou-me embora". Então ele me disse assim: "o que você fez é uma coisa grave, porque você desobedeceu-me gravemente", então eu disse: "não, o que eu fiz é o que tinha pra fazer, não podia ficar num lugar onde não estava 
a me sentir bem e ainda tinha que brigar todos os dias pra manter as atividades das coisas". Então mandou-me para a paróquia mais pobre da diocese e disse: "olha, não é um castigo, mas é que eu não posso te mandar para uma paróquia muito boa, porque senão vão dizer que além do mais ainda te premeio". Eu disse, "não, não tem problema, eu vou pra qualquer lugar que eu me sinta bem, onde eu possa exercer o meu ministério com dignidade, não tenha que fazer coisas que vão contra a minha consciência". Então fui pra lá, eram três aldeias ou quatro, que era Rio de Onor, Petisqueira, Beirão e Miramia, todas pequeninas, tudo junto, não dava 200 focos, eram muito pequenas, e os padres, em geral, gostam de paróquias grandes, porque recolhem muitos provimentos. Essas minhas eram muito pequenas mesmo, pobres mesmo. Eu fui condenado à pobreza, mas não me entristeceu nada, até porque fiquei muito satisfeito, não só porque eu gostava daqueles lugares, que eram os lugares mais recônditos do distrito de Bragança, mas porque era gente pobre, era gente muito humilde, era gente que eu podia ajudar realmente. Eu não fui para lugares que eu podia ficar rico, era gente pobre, que eu podia ajudar até com o pouco que eu tinha. Comecei a introduzir algumas fórmulas novas, eu, por exemplo, não recolhia uma coisa que se chama "congro", os aldeões não me davam nada pessoalmente, eu não recebia nada deles. No princípio, recebi, mas depois disse assim, pá, isso é muito mais do que eu ganhava lá na cidade, então passei a não receber nada pelos batizados, pelos casamentos, essas coisas, e exatamente aquele pouco que ajudavam, ainda me sobrava. Isso criou um problema com os outros padres, porque os outros recebiam as duas coisas. E o bispo me disse: "mas por que você faz isso", e eu disse "aquilo que é ajudado no congro é mais do que eu recebia lá na cidade, então por que agora vou receber mais se eu faço até menos?" [Alípio de Freitas]. Fui criando algumas dificuldades. Ao fim de dois anos, eu saí, pedi licença ao bispo e fui para o Brasil [por volta de 1957]. Não sabia nada sobre o Brasil, nada. Nem pouco, nem muito. Fui para o Brasil e fui para o Maranhão. Não sabia bem onde era o Maranhão, nem o que ia fazer no Maranhão, fui assim meio... Escrevi ao bispo do Maranhão, a perguntar se me recebia, ele disse-me que sim, precisava de mim até porque precisava de um professor de história antiga na universidade, se eu podia ir, se eu aceitava etc. Fui bem recebido, ele recebeu-me lá, fiquei na casa dele a morar, fui professor da universidade, fiz exames etc. E aí, fiquei um tempo lá, uns dois anos nesse lugar, mas a certa altura, comecei a tomar conhecimento do que se passava à volta, em São Luís, na cidade, que era pequena, em termos de Brasil. Era uma cidade muito pobre, muitas casas de pau a pique, de maré. Era uma cidade colonial muito boa, mas depois o comércio mudou-se e aquilo ficou tudo no abandono, então tinham pessoas que ficaram ricas e o resto era tudo pobre. $\mathrm{E}$ depois aconteceu o seguinte, o pessoal começou a imigrar do interior pra cidade, imigrou, mas não trouxe terras, não trouxe nada. Como fazem sempre as terras do latifúndio: o latifundiário os deixa sair ou não deixa. Mas não deixa trazer 
terras. Então os que moravam no interior do Estado ficaram pobres na cidade.

Diego Pacheco e Tiago João José Alves: E a sua formação política e seu engajamento, quando ocorreram?

Alípio de Freitas: E um dia começa a minha saga realmente porque enquanto dei aulas esteve tudo bem, tudo tranquilo, sem problemas.

Diego Pacheco e Tiago João José Alves: Não tinha contato algum com a teologia da libertação ou com as ideias socialistas?

Alípio de Freitas: Não. Eu tinha, assim, contato com as pessoas mais ligadas à esquerda etc, mas efetivamente, digamos, como militância, não tinha grande ligação. Na Universidade eu tinha contato com o pessoal e tal. Porque eu aqui em Portugal, eu não tinha muito contato com essa gente, porque eu morava lá no Norte, e aqui em Portugal, tirando Lisboa, Coimbra e o Barreiro, não se via nada em lugar nenhum. Eu posso dizer, por exemplo, que eu nunca vi uma manifestação política, nunca vi uma prisão de trabalhadores, nunca vi uma manifestação de trabalhadores. Sabia que existia a PIDE [Polícia Internacional e de Defesa do Estado], mas sabia que existia por saber. O fascismo [em Portugal] tinha uma faceta especial (já estava implantado há tanto tempo e por ter destruído a sociedade resistente). Eu nunca vi uma prisão política, eu nunca vi nada dessas coisas, eu nunca ouvi falar sequer. Então, eu não tinha nenhuma informação sobre política, ouvi falar da Guerra Colonial, mas em princípio, imagine, eu até achava bom Portugal fosse para a Guerra Colonial. Eu fui para o Brasil, quando foi o segundo batalhão expedicionário pra África, então, até eu achava bom porque tinham me dito na escola primária, e isso eu nunca tirei da cabeça, que Angola era província de Portugal, como era o Trásos-Montes, que Moçambique era uma outra província de Portugal, como era, sei lá, Beira Alta. Então não tinha nenhum conhecimento disso, e que a tropa que ia pra lá, ia pra segurar os pequenos movimentos, dar rufadas no pessoal que se meteu a querer se libertar. Mas libertar de quem, de que? Até conheci, mais tarde, alguns dos líderes angolanos, já depois disso. Mas eu não tinha nenhuma informação sobre a Guerra Colonial, sobre a PIDE, sobre o Tarrafal [Colônia penal criada durante o salazarismo], sobre as prisões políticas, não tinha nenhuma informação, zero informação. Então cheguei ao Brasil, em plena guerra da Argélia, e um dia encontro-me a discutir com um aluno meu sobre isso, e eu defendia a guerra da Argélia, ele não, era contra os franceses. Depois fui pra casa e disse: "vou falar com o Bugarin (aluno de Alípio) de novo sobre esse assunto" e fui falar com ele. E disse, "ó Bugarin, você pode ir comigo para discutirmos sobre a guerra da Argélia?", e ele disse assim: "pois é, precisamos conversar". Eu disse que os franceses tinham razão e ele disse-me que não, que não era assim, então pela primeira vez ouvi alguém por em causa a guerra da Argélia. Porque pra mim na guerra da Argélia, os franceses tinham razão 
e os argelinos não tinham razão nenhuma de fazer aquela guerra. Isto era a minha cabeça. É claro que nas aulas eu não tinha que dar isso, eu dava História Antiga e [História] Medieval, então não tinha nada a ver com essa história, diretamente não tinha nada a ver, indiretamente teria: as ocupações, certo? Mas, pronto, mas passava a malés tudo isto. E os jornais do Brasil também não falavam muitos sobre isto, não muito, ou quase nada. Havia apenas um jornal, que se chamava Semanário, eu até acabei trabalhando neste jornal um tempo mais tarde, era de um amigo meu [Osvaldo Costa]. Era o único jornal, no Brasil, que colocava essas questões corretamente. Bem, então comecei a ler o Semanário. Achei o Semanário um jornal extraordinário, trazia coisas que nenhum outro jornal trazia.

Eu, um dia, estou num jornal, $A$ Voz do Povo, que era do Hélio Moreira, e estavam lá reunidos uns quantos. Eram conhecidos meus, que estavam a discutir a legalidade ou não do despedimento de 600 trabalhadores numa fábrica têxtil, que era pra ser vendida a uns americanos. Era de um português essa fábrica. E todos estavam de acordo, que podia ser vendida, e que eles não tinham direito à indenização nenhuma. Inclusive, o líder dos têxteis de São Luís, disse-me assim: "mas como, tem 600 pessoas que trabalharam nesta fábrica, trabalharam uns tantos anos, uns vários anos, e de repente são postos à rua, sem nenhuma indenização e ainda mais, perdendo as casas que tem, o que é isso?". E dizme assim, o secretário do sindicato: "pois é, mas é assim mesmo, estão sendo demitidos por justa causa". Eu disse: "justa causa? Mas que justa causa é essa? O sujeito trabalha, trabalha todos os dias, não dá faltas, e depois ao fim de, não sei quantos anos, alguns 30 anos, é posto na rua assim como se fosse lixo, o que é isso? Como é que você, sendo líder sindical desses trabalhadores, acha que há justa causa?". Mas no fim, todos os outros que lá estavam, e eram todos de esquerda (até havia algum que era comunista, o Trinbuzi, que era do partido mesmo), disse: "não, não é bem assim, mas na verdade ele pode os por na rua". Eu disse: "não, ou estou louco ou vocês estão loucos porque eu não entendo nada de direção agora no Brasil, nem pouco nem muito, mas é o meu bom senso que diz que não pode ser, pronto, acabou". Aí eu saí e fui comprar um livro de direção laboral, fui na universidade debater sobre isso com um colega. E lhe disse estou cá com um problema que é o seguinte, e ele disse "já sei, já sei, é a maior maracutaia que tem aqui", me explica essa história, não consigo entender isso, não é que eu entenda alguma coisa, mas não me cai bem isso, pronto. Então ele me explicou tim tim por tim tim o que estava a acontecer, tivemos uma noite inteira, ele a explicar e eu a ouvir, a tomar nota. Quando saí de lá eu tive a impressão que sabia toda a organização laboral, não havia nada que eu não soubesse, estive tão atento àquilo. No dia seguinte, escrevi um artigo num jornal pequeno a favor dos trabalhadores, com aquilo que eu aprendi com meu colega na universidade. $\mathrm{O}$ artigo nem sequer era violento, apenas dizia as coisas que me pareciam corretas. Bem, a imprensa de lá botou- 
se a mim que parecia Santiago aos mouros. Bem, mas o povo da rua não, o povo foi para a praça principal e aquele deu um comício, ocuparam a fábrica, isso só porque escrevi um artigo. Acontece que o arcebispo estava no Rio e os donos da fábrica mandaram um aerograma para ele dizendo que eu estava atacando a família que era dona da fábrica. E eu nem citava o nome da família. $\mathrm{O}$ arcebispo mandou uma resposta dizendo pra eu não atacar a família. E como não estava atacando a família, escrevi no mesmo jornal, uma coisinha assim: "não podendo, porém, o impedimento da autoridade eclesiástica continuar a defender os operários da camboa e desfaço a defesa aos trabalhadores". Aquilo foi um fuá, aquilo foi rastilho. Nesse ínterim fiz uma coisa que eu condeno pessoalmente: fui ao diretor de um jornal imparcial, que era dos Associados, que era também professor na universidade, e lhe disse assim, ó Sabóia: "você escreveu esse artigo aqui no seu jornal, eu gostaria que isso não se repetisse, porque se isso se repetir, eu venho aqui com quatro estivadores e quebro tudo isto que não deixo nada em pé, lembre-se que estou a dizer: empastelo isso tudo e não deixo nada em pé. E ele disse: "ah, mas não é caso pra isso". Pra mim é, se você escrever mais uma linha contra os trabalhadores da camboa, eu venho aqui com quatro estivadores e não deixo nada, nada em pé.

Bem, no final, aquilo foi para julgamento. Eles tiverem de indenizar os trabalhadores, perderam as casas que ficaram com os trabalhadores que moravam nelas, e não puderam vender a fábrica porque os americanos não quiseram mais. De aí em diante, tudo quanto era greve, ou qualquer coisa nesse sentido, eu estava sempre lá, passei a ser necessário estar lá, às vezes não era, mas eles queriam que eu estivesse lá. Então passei a fazer parte de toda a vida sindical do pessoal etc. E nisto, eu deixo a universidade, estava farto já, e um dia deixei e disse: "bem, o que faço aqui, qualquer outro pode fazer, então fuime embora". O bispo me mandou-me pra uma paróquia que era um subúrbio, pobre como eram todos os subúrbios, então eu disse: "pra fazer o mesmo que fazem todos, não vale a pena". Então comecei a inventar. Celebrava a missa em português, celebrava casamentos de todo mundo, enfim, batizados em português, tudo era em português. Eu conclui com eles, que se não sabiam português, teriam de ir a escola. Montamos escolas para todos os miúdos, isso com apoio de todas as pessoas do bairro, eram três pequenos bairros, um deles, a única casa com telha era a igreja, o resto eram todas casas com palha, cobertas de palha, a minha mesmo. Pusemos posto médico, com esse amigo meu que disse pra não ler o Semanário, pusemos outro posto médico com a médica que era secretária do PCdoB. Enfim, organizamos. Mas isto era assim, a noite, toda a missa era de noite. Então eu fiz assim, eu fiz um levantamento de toda a população da "favela", rua por rua, casa por casa. E depois já noite, no alto-falante que eu tinha, eu disse assim: "bem, todos querem missa, tá bem, então é assim: como a igreja não dá pra todo mundo, e todos querem vir à missa, vamos fazer assim. Na segunda-feira tem a obrigação de vir à missa fulano, 
cicrano e beltrano, que são da rua tal. Na terça-feira a obrigação é de fulano, beltrano, cicrano, como nome de rua tal." Então todas as ruas ficaram cobertas com a sua obrigação de missa, porque missa pra mim era importante, porque era na missa que se discutia tudo. Discutia se o menino estava na escola, se havia alguém doente na rua, quem é que estava empregado ou desempregado, porque eles sabiam tudo daquela rua, moravam ali. Então perguntava-se assim: "quantos meninos há na rua que não tem escola? Cinco? Então cinco meninos pra escola". Então montamos as escolas que eram pau a pique e palha, quantas foram necessárias para metermos os meninos lá. Professores, a secretaria de educação não mandava. Contratei umas meninas que sabiam ler e escrever, um pouco mais que isso, lhes dava um salário, e elas dava aulas aos meninos de manhã e de tarde. Então sempre tinham algumas cinco escolas, todas desse tipo. E elas diziam: "fulano não veio". E eu na missa, no dia seguinte: "fulano não veio, o que ele estava a fazer? Ah, ele estava doente? Por que não foi ao médico?". Então a missa era isso, era uma conversa. E depois inventei mais, inventei o seguinte: o marido duma rua lia o evangelho, e a mulher lia a epístola, e depois o marido explicava o evangelho, às vezes era a mulher que explicava. Todas as coisas se fazia na igreja, era o centro da autoridade eclesiástica, que quase não havia, mas era de toda atividade que existia naquela raia. E isso criou alguns problemas: primeiro - os outros padres não achavam nada bom nisso porque eles não estavam pra se matar e fazer isso; e segundo - as pessoas das outras paróquias iam lá e diziam assim: "ah, seu padre, eu fui à missa da floresta, lá é muito mais interessante, lá eu entendo, lá é em português, quem prega é o fulano, lá até os professantes pregam”. Porque teve, numa altura qualquer, um grupo de protestantes que morava lá na minha rua mesmo, foi lá e disse assim: "nós moramos na sua rua, somos seus paroquianos, então podemos vir cá à sua missa?”. [Alípio]: “É claro, podem e devem.” Iam, estavam lá enumerados e faziam lá o que os outros faziam. E todo mundo queria casar lá, batizar lá, isso criou alguns problemas pra mim. A rapaziada comportava-se muito bem nesse aspecto, não tinha problema. Mas eu tinha, porque tinha que enfrentar os problemas dos padres e às vezes dos bispos. Com os bispos era mais fácil, eles diziam: "eu só não quero saber o que está a acontecer". E eu dizia: "não é por mim que vai saber, se quer saber tem de ir lá ou mandar alguém lá pra dizer". Aquilo foi se tornando cada vez mais difícil a minha sobrevivência no lugar.

Diego Pacheco e Tiago João José Alves: Isso antes do Concílio Vaticano? Alípio de Freitas: Sim, que Concílio Vaticano, vinha longe ainda. Quando me falaram: "olha, Deus não sabe português." Eu disse: "não? então que aprenda, nós também aprendemos, então ele tem de aprender." A última celebração que eu fiz lá foi num Natal, eu quis fazer um Natal na rua, especial. Estas festas todas se faziam na rua. Por exemplo, se alguém quisesse fazer uma festa de aniversário, punha as mesas na rua, eu celebrava a missa na rua, todos 
participavam da missa, participavam da festa e essa coisa. A minha banda de música era um Bumba meu Boi, eu participava disso. Todas as vezes que tinha festa grande, o Bumba meu Boi é que funcionava. E nesse Natal, por acaso, tinha uma vizinha que estava grávida para ter um menino. E eu estava a pedir assim, não sei a quem, pra que ela tivesse esse menino no Natal. Porque eu estava com aquela de fazer um Natal pra ela ter um menino na praça. Eu tinha lido um livro francês que falava sobre um Natal na praça, a ideia não foi minha. Aquilo aproximou-se, enfeitaram as ruas, a rua principal que era a rua Tomé de Souza, uma rua comprida e larga, ninguém sabia o que ia acontecer. Mas todo mundo colaborava, punha luz. Nunca pagávamos energia elétrica. Tínhamos uns eletricistas que trabalhavam lá na eletricidade, eles faziam a iluminação para as festas, nunca se pagou nada, eles faziam isso tudo. E então, fizemos iluminação, fizemos tudo, fizemos uma espécie de trono, com a cadeira alta assim, pra se sentar alguém, e eu celebrei a missa e tal, e depois fiz o beija a mão do menino. Antes do beija mão, lá desce a Dilma, desce rua abaixo, deitada num burro, com um menino aqui assim, e vinha o marido dela, se chamava José, atrás, segurando a rédea da burra. E quando eles apareceram, as palmas, os cânticos, a alegria, o baile, todo mundo dançava. Eu fui o primeiro a beijar o pé do menino, depois todo mundo beijou o pé do menino e tal e tal. Depois todo mundo sentou-se a comer, a bailar, a beijar o menino, a soltar foguetes, e entrou noite adentro, até clarear o dia. A Dilma foi pra casa com o Zé. E eu fui o primeiro a beijar o pé do menino e tal, e isso foi um escândalo, porque o menino era preto. No dia seguinte, os jornais acharam a festa muito linda etc, mas, o menino Jesus era "preto", era o que os escandalizava, não foi a festa, foi o menino ser "preto". Teve o Bumba meu Boi, enfim, foi coisa fantástica. Aquilo feito no cinema arrastaria gente até hoje. E nesse dia, no fim da festa, eu disse assim a um companheiro chamado Augusto, que já morreu, que é o meu pai espiritual dentro do movimento revolucionário camponês. Eu disse: “Augusto, posso ir lá pra tua casa?”. E ele disse, “pode”. Bem, fiquei lá até o fim da semana, mandei dizer ao bispo que eu já não estava mais naquela paróquia. Porque eu podia continuar na paróquia, o bispo não podia me tirar de lá, aquilo continuava, então talvez ele achasse que era aquilo mesmo.

\section{Diego Pacheco e Tiago João José Alves: E quando o senhor conheceu o Augusto?}

Alípio de Freitas: Num dia 7 de Setembro, aquela festa, aqueles discursos, aquelas coisas, em São Luís também. E me encaminho lá para Academia Maranhense de Letras, onde ia ser os discursos, com o governador, o arcebispo, os militares, toda essa gente. Então fui lá e sentei-me do lado de um tipo que se chamava Augusto, era um camponês, eu o conhecia bem. O conhecia dessas minhas brigas por causa das fábricas, e então, falaram todos da pátria, porque a pátria, pátria pra cá, pátria pra lá, toda essa história. E o falatório da pátria 
durou horas. E quando estava tudo terminado, o governador levantou-se e disse assim: "se alguém quiser dizer algo ainda, pode se levantar, a cátedra está ali, pode falar". O Augusto mexeu-se e encaminhou-se para tal cátedra. Fiquei surpreendido só, o resto do pessoal ficou temeroso, tinha muita gente. E eu pensei, "bem, o Augusto vai apanhar de porrada e vai preso, porque ele é desbocado e vai dizer coisas que o governador não gosta". Daí o Augusto foi lá, subiu, saudou todo mundo, muito bem, bateram muitas palmas, e depois disse assim: "hoje é o dia da pátria, mas eu também sou brasileiro e não tenho pátria. Eu sou um camponês sem pátria, não tenho terra, não tenho casa, não tenho família. O governador tem pátria, é formado em direito, senhor arcebispo também tem pátria, o senhor presidente da câmara também. Agora nós, os trabalhadores, os camponeses, não temos pátria. Não temos casa, não temos trabalho, terra, não temos família, não temos nada. Somos nós que morremos pela pátria, o senhor governador deve saber disso, porque ele esteve na guerra da Itália e ele veio. Mas e os que ficaram lá no cemitério? Tem pátria? Morreram pela pátria? Não, porque eles não tinham pátria, eles morreram porque os mandaram pra lá e eles foram, morreram sem pátria.". Por aí adiante, foi nesse tom... E quando acabou, foi uma salva de palmas tão monumental, que parecia que o teatro vinha abaixo. E o pessoal dizia assim: "o Augusto vai tomar uma salva de porrada", mas não. O governador veio, o cumprimentou, disse que queria falar com ele etc. E quando ficamos só nós dois, eu disse: "Augusto, eu posso ir pra sua casa hoje?" E ele disse: "claro, tem duas redes, uma pra você e uma pra mim”. Fomos pra lá e ficamos até o fim da semana começar. Quando chegou no dia de sair, eu disse que tinha de ir à missa. E ele me perguntou se podia ir junto, eu disse que sim, claro, a missa era pra todo mundo. E ele foi. E o meu compadre, que era estivador, e ele disse, "olha, Augusto, você por aqui, então você vai ler o evangelho e depois vai fazer a explicação, tudo bem?". O Augusto aceitou. Fez a leitura do evangelho, deu a sua explicação, no fim todo mundo bateu palmas. E depois, estávamos a sós, diz-me assim: “olha, amanhã vai ter uma reunião de camponeses em Coroatá [município do Maranhão], eu vou sozinho, não quer ir comigo?". E disse: "claro, vou contigo". Pronto, daí em diante, andamos juntos até ele desaparecer, no Sul do Maranhão, não sabemos onde ele morreu. Ele andou comigo por esses anos todos e ele nunca teve nada, só tinha a roupa do corpo e algum dinheirinho que a gente dava pra ele. Hospedava-se nas casas dos camponeses, conversava com eles, mudava para outro lugar. Era um militante como eu nunca vi outro. Sem o Augusto, seguramente eu não estaria aqui a conversar com vocês. Porque tudo o que sei sobre o campo, e outras coisas, foi ele que me passou, que me ensinou.

O Augusto era um camponês magrinho, baixinho, que nasceu no Pernambuco, lá numa fazenda. Como era muito franzino, não o obrigavam ao trabalho. Ele aprendeu a ler, lia essas estórias do Lampião, essas coisas. E tinha um miúdo que era filho do patrão, brincavam juntos, mas de vez em quando o filho do 
patrão lhes dava umas porradas e o Augusto não gostava nada disso. E um dia, ele pegou o filho do patrão de jeito e deu-lhe uma surra a sério. E aí pensou sobre o que ia acontecer depois disso, temendo apanhar do pai do miúdo. Juntou a sua trouxinha numa sacola e foi para Recife, onde é que tinha um padrinho. Chegou lá, contou a história, o padrinho diz assim: "aqui mesmo você não está seguro, pois enquanto ele souber que estás aqui, dá-te uma surra e te joga no mar, acho melhor tu saíres daqui, vamos tratar disso". Enviou-o para São Paulo aos cuidados de um capataz do porto para ele cuidar da vida dele lá. O Augusto chegou, lá tinha um sujeito à espera, mas como ele era franzino, e não era estivador, e pra se entrar na estiva era preciso ter bom físico, ele foi trabalhar na obra do Hospital das Clínicas que estava ser construído. Lá trabalhou, dando serventia aos pedreiros, um dia, ele vendo uns tijolos, achou um papel, e o enfiou no bolso. A noite, lá no barraco que ele dormia, ele leu o papel e pela primeira vez ouviu falar da revolução mundial e da Rússia, essa coisa toda. Sonhava todos os dias com isso. No outro dia que também estava a dar serventia, encontrou outro papel no chão pra levar ao bolso. Mas não foi tão rápido, um capataz viu e disse: "então é você que apanha esses papéis? Você apanhou outro em tal lugar, você já está a saber muita coisa". Augusto disse que não sabia de nada e o capataz lhes disse: "hoje à noite tem uma reunião do pessoal que apanhou papéis, e se você quiser ir, diga logo". Augusto disse que queria ir e perguntou onde era a reunião, mas o homem disse assim: "bom, mas você já está querendo saber demais, você vai comigo e vai ver onde é, por que e se você for da polícia”. De noite definiram um ponto e foram para a reunião. O Augusto ficou enlouquecido com o que ouviu, a revolução, Stálin, o socialismo, essas coisas todas, isso já era nos anos 1930, 1940... E o Augusto começou a falar, em segredo, com outros companheiros, até que o pessoal achou perigoso ele ficar ali, pois não se contentava em saber, queria transmitir a boa nova. Para ele, a revolução tinha de ser feita logo, com urgência. O senhor que o contatou, disse: "Augusto, você tem de fazer uma tarefa urgente, é o único capaz de fazer. Você tem de ir para o Maranhão, até que nós o chamemos ou que alguém o chame porque lá temos um trabalho muito importante pra fazer". Não era isso, era para afastá-lo dali, porque o Maranhã ficava longe de São Paulo e ele não conhecia ninguém lá. Ele enfiou suas coisas num saco, entrou num navio e desembarcou em Tutóia [município do Maranhão]. Como ele não conseguia ninguém, pensou: "todos os munícipios fazem obras, estradas, caminhos etc." Foi à câmara, disse ao presidente: "olhe, sou especialista em fazer estradas e caminhos, o senhor não está precisando de alguém que faça isso?". O presidente da câmara disse que sim. Augusto juntou uma equipe para fazer as obras, mas o interesse dele era o de conversar com as pessoas. Nos anos que esteve lá, fez mais de 50 associações, e nunca mais chama ninguém de São Paulo para falar com ele, mas ele sabia que havia de chegar alguém. E então, um dia chega alguém de São Paulo pra ele ir numa reunião a São Luís, 
era o pessoal do partido, era a primeira reunião. E foi, viu lá pessoas que ele conhecia. Falaram de Stálin, de Lênin, de coisas que ele não sabia nada, mas que queria ter sabido. Soube que houve a mudança do Lênin para Stálin, não sabia quem era um, nem quem era o outro, mas percebeu que houve alguma maracutaia ali. De qualquer maneira, ficou secretário do partido lá praquela região, já onde ele mandava. E quando falavam de revolução, o pessoal dizia assim: "bem, mas isso não é pra já, isso vai demorar um tempo". E ele dizia: "vocês não precisam fazer revolução nenhuma, todos já tem emprego, trabalho, já todos vivem bem. Agora para nós os pobres precisamos da revolução logo, e estamos aqui a perder tempo nisso." Mas depois se perdeu tempo... Ficou lá mais um tempo e foi para São Luís.

E fui eu quem lhe contou a história da desestalinização, essas histórias todas que aconteceram na União Soviética e que ele não sabia. Ele ficou muito furioso com esse pessoal, qualquer coisa que ele queria saber a sério da União Soviética, desses lugares, era comigo que ele falava porque ele sabia que eu não o enganava. Fiz com ele uma grande amizade. Ele queria a revolução pra ontem, não era pra hoje, trabalhava todos os dias para revolução. Qualquer coisa que ele fazia, o sentido de fazer dele era o hoje, para a revolução. E eu sempre digo: se não estivesse encontrado o Augusto, talvez eu estivesse ainda, não nessa paróquia, mas noutra qualquer, a fazer a mesma coisa. Porque ele foi um motorzinho pra mim, ele despertou a minha consciência pra necessidade da mudança, pra urgência necessária de mudar as coisas.

\section{Diego Pacheco e Tiago João José Alves: E é nesse momento que o senhor deixa a Igreja?}

Alípio de Freitas: Deixo a igreja com o Augusto, a última missa que celebrei foi com ele presente. Depois vou ao Rio, ao Recife e vou à União Soviética. Fui para a URSS a cargo de ninguém, depois quando vim, deixei a igreja definitivamente, aí entrei nas Ligas [Camponesas]. Não voltei para o Maranhão, fiquei em Pernambuco. E em Pernambuco eu entrei nas Ligas, fiquei nas Ligas e na Ação Popular (AP).

Diego Pacheco e Tiago João José Alves: E o Augusto desapareceu quando? Alípio de Freitas: O Augusto desapareceu depois do golpe [civil-militar de 1964 no Brasil], já tínhamos fundado a Ação Popular. O Augusto morreu dentro da Ação Popular.

\section{Diego Pacheco e Tiago João José Alves: E a Ação Popular, como foi fundada?}

Alípio de Freitas: A Ação Popular é uma coisa difícil de falar. Ela começa, acaba, começa, acaba. E ela vai se mantendo com alguns nomes, mas ela nunca foi uma grande força, quando tinha força era nalgum lugar, depois havia outros 
que não tinha, havia outros lugares que nem existia. Nunca foi do Rio Grande do Sul à Amazônia. A Ação Popular sempre teve uma direção muito vacilante. Por exemplo, eu fui pra Cuba com o Paulo Stuart Wright e mais outros quatro rapazes que não eram da Ação Popular, mas que haviam entrado na AP. Fomos para treinar com a intenção de voltarmos e organizar a luta armada no Brasil. Chegamos lá, eu e o Paulo chegamos antes, eu cheguei primeiro e ele chegou logo, depois chegaram os outros companheiros que não eram da AP e haviam sido captados quando estavam na Embaixada do México.

Diego Pacheco e Tiago João José Alves: Isso foi depois do golpe no Brasil? Alípio de Freitas: Sim, depois do golpe. A AP já existia, porque ela criada em Belo Horizonte. Mas o pessoal que fundou a AP nunca pensou que houvesse golpe, quando o golpe se deu eles não estavam preparados nem ideologicamente para o golpe. Eles estavam preparados ali pra fazerem alguma coisa, mas, digamos, nada que afetasse o golpe violentamente, nenhum deles, nem o Betinho [Herbert de Souza], nem ninguém. Bem, fomos lá pra Cuba, fomos fazer o treinamento, fizemos o treinamento. Depois o Betinho esteve em Cuba, a AP tinha recebido um cachê qualquer de Cuba no sentido de nos ajudar a começar a AP. O Betinho esteve em Cuba, comigo e sozinho, inclusive, mas não me disse uma sequer palavra sobre isso, eu venho a saber isto no Brasil já. Porque ele foi lá exatamente pra desfazer o acordo da Ação Popular, quer dizer, o Beto e o Aldo Arantes, eles é que fizeram esse acordo, pelo menos esses dois. Mas depois, como não queriam fazer a guerra popular, eles desfizeram isso com Cuba. Dizem eles que foram entregar o dinheiro lá em Cuba, mas não sei também, porque não me disseram nada sobre isso. Eu estive com o Betinho sozinho durante um dia inteiro, a conversar, sobre coisas do Brasil, não sei se eram verdadeiras ou falsas etc. Depois sai de Cuba para fazer outras coisas e fui pra Argentina. Eles sabiam que eu estava na Argentina, sabiam com quem eu estava ligado na Argentina. Mas nunca deram um passo pra se encontrar comigo na Argentina. Era fácil, era atravessar o rio [Alípio: ri]... E uma vez fui encontrar aqueles tipos, cheguei ao Uruguai, no dia que o Betinho e o Aldo estavam regressando ao Brasil, sem dizer nada a ninguém. Porque o resto da turma da AP já tinha se debandado, ou tinha saído, ou tinha desaparecido, eles não conseguiram manter. Eu sei que eles foram para outros lugares. Bem, nessas condições eu voltei pra Argentina, fui para a Argentina para a organização com que eu estava a trabalhar, continuei o meu trabalho na Argentina. Até que um dia, já passado muito tempo, numa conversa que tive com um pessoal (não sei se eram dos Montoneros), e um disse-me assim: "vai ao Brasil, vê onde está esse pessoal, senão, entras aqui, ficas conosco e acaba essa estória do vai e volta". Fui o que fiz. Peguei uma trouxa e fui a São Paulo, fui por terra. Cheguei em São Paulo, fui ter contato com o sujeito que sabia onde estava o Aldo. O Aldo quando me viu é como se tivesse visto o diabo. E 
ele: "tu aqui?", e eu disse: "pois estou aqui, porque eu ainda sou da AP, vocês não dizem nem vai ou nem vou, então quero saber se a AP ainda existe ou se vocês não me consideram da AP. Bom, se vocês me consideram, vou fazer uma tarefa que acho necessária para a guerra revolucionária". Ficou assim, me olhou, mas não disse nada. Eu me mando pra Goiás e com outro companheiro escolho três lugares para fazer campo de treinamento, acampamentos seguros. Passo mais de 50 dias andando por lá, a pé, e outro companheiro que foi assassinado. E aí, venho a São Paulo, e digo ao Aldo: "a tarefa está cumprida". E diz-me assim o Aldo, com a maior cara de pau: "mas essa já não é a política da AP". E disse: "em quarenta dias vocês mudam de política e não avisam a ninguém?". [Aldo Arantes]: "é, nós já não estamos mais na luta armada". E eu disse assim: "vá ao caralho, vocês são todos uns filhos da puta! É o que vocês são". E aí, o Raimundinho, de Minas Gerais, falei com ele e ele me diz assim: "vamos continuar as coisas", mas logo ele morreu. E depois, eles [AP] como ficaram no mato sem gato, nomearam o Wright para a direção militar da AP. Mas enganaram-no. Porque eles três, Aldo, Betinho e aquele baiano, já tinham decidido que não haveria ação militar nenhuma, eles já tinham mudado até, já não eram mais pró-chineses. Eu continuei a andar por aí, vou continuar essa história e vamos ver no que é que dá. E depois é que se organiza esse grupo final que fui preso (não me recordo como se chama, já não me recordo, tinha alguns da $\mathrm{AP}$, outros que não eram da $\mathrm{AP}$, como o Augusto etc) [Alípio deve estar se referindo ao Partido Revolucionário dos Trabalhadores (PRT), liderado por ele, Vinícius Caldeira Brant e Altino Dantas]. Nessa altura eu estive pra voltar à Argentina, só não voltei porque o Mariano, o companheiro de Minas Gerais, disse: "não, nós organizamos aqui as coisas e tal". Porque estava tudo tão desorganizado, não havia nenhum grupo que tivesse 10 sujeitos naquela altura. A revolução brasileira, desde sua gênese até o seu fim, é uma extrema mentira. Foi sacrificando pessoas inutilmente, não levou a lugar algum. Isto por falta de organização e porque os líderes, dessa dita revolução, não tinham nenhuma noção do que era fazer revolução. E nesse aspecto refiro-me também ao Carlos Marighella, me refiro ao Carlos Lamarca. Queriam fazer guerra revolucionária, mas não tinham nenhuma noção do que era a guerra revolucionária, nem o que era a guerra revolucionária num país como o Brasil. Tinham apenas um voluntarismo, queriam fazer uma coisa, mas não tinham nenhuma noção disso. Essas são as reflexões que eu tenho depois, na altura que já não adianta mais nada essa coisa, estás a entender?

O que seria normal, naquela altura, na altura que eu fui preso já, era ter saído do Brasil, esperado um tempo e tentar fazer organizações de massa. Mas era difícil porque os militantes não tinham a mesma ideia que nós temos. Depois acontece o mesmo no negócio do Araguaia [guerrilha], porque o Araguaia não é uma coisa nova na revolução. O Araguaia é uma coisa que acontece ainda antes do Partido Comunista do Brasil (PCdoB) tomar conta da ideia. Eu escrevi 
até um papel sobre o Araguaia e discuti mais tarde, tem uma porção desses caras que são coronéis do exército, longamente. Uma guerra revolucionária é sempre é uma guerra muito prolongada. Ali ninguém estava preparado para fazer uma guerra prolongada. Todos queriam uma guerra prolongada, mas que durasse 8 dias, no máximo, porque era prolongada para durar 10 anos, 15 anos. Todos se baseavam na guerra prolongada chinesa que durou 20 anos, não foi duas semanas nem 20 dias. Agora, por que ela durou 20 anos? Porque durou 20 anos. Nós não tínhamos nenhuma condição pra uma guerra de 20 anos. Primeiro faltavam-nos um partido a sério, o PCdoB não era um partido a sério, nem sequer era um partido sério. E os outros partidos não eram partidos, eram grupos, que tinham vontade de fazer isso ou aquilo, mas que numa semana ou duas, no máximo, já começavam a vacilar. Eu digo isso de todos, incluo-me nisso também, ainda que isso é produto de muita reflexão nos anos que estive preso. Não estive na prisão a comer tremoços, estive a pensar, tinha tempo pra pensar, conversava com as pessoas, tinha discussões. Havia muitos que não tinham nada, que dormiam apenas, havia muitos que para tirar do sono era quase preciso bater. Nem todo mundo passou o tempo a estudar, a ler, a discutir. A prisão foi boa, digamos boa, para quem a aproveitou, porque muitos passaram aqueles anos todos sem ter aproveitado nada dentro daquele espaço. Passaram por ali estando de férias, num lugar terrível, mas de férias, sem fazer nada, sem pensar em nada. A não ser pensar no dia em que iam sair. Os marinheiros pensaram em sair apenas, mas os que não foram presos como marinheiros podiam ter pensado noutras coisas. Mas a grande parte não pensou em nada, a prova está em que saíram e procuraram emprego, ou entraram em algum partido que lhe deram emprego. Onde é que estão os caras que eram militantes? Os que saíram militantes, saíram militantes, mas não fizeram nada, ou fizeram algo muito mal. O cara que é militante sai de uma situação, mas a partir de uma situação ele vai criando outra situação. Porque era difícil encontrar emprego, os empregos que encontrava, era aqueles tipos de empregos que o sujeito tendo vergonha, não aceitaria. Eu, por exemplo, para encontrar emprego estável, fui para Moçambique.

\section{Diego Pacheco e Tiago João José Alves: Como o senhor via o ambiente político e social do Brasil no período anterior ao golpe de 1964?}

Alípio de Freitas: Hoje, eu tenho a seguinte posição. Se os militares tivessem entendido a situação, porque o Jango [João Goulart] não queria o golpe, ele queria, demonstra-se perfeitamente, pelas atitudes que ele foi tomando durante o golpe. O Jango queria um golpe de Estado que o colocasse com todos os poderes, ou seja, fechar o congresso, era isso que ele queria. Já não era a primeira vez que acontecia. O Jango queria o fechamento do congresso e governar sozinho com quem ele quisesse. Não fez isso porque a esquerda não deixou, toda a esquerda, digamos, sobretudo o congresso, não deixaram, porque 
os militares estavam dispostos a the conceder isso mais do que o golpe. Como os militares não lhe concederam isso, o Jango fez o que achava conveniente, foi-se embora e largou aquilo nas mãos dos militares. O Jango não foi obrigado a sair, saiu porque quis. Porque ele já tinha mandado para o congresso, pela mão do [Roland] Corbisier, não estou a falar de pessoas desconhecidas, um documento para o pessoal do PTB [Partido Trabalhista Brasileiro] para que fosse analisado esse documento a fim de pedir o fechamento do congresso/impeachment [estado de sítio]. E o pessoal do PTB não aceitou esse documento, eu vi o documento, inclusive. Não aceitou esse documento e disse: "não, resistiremos ao Jango e aos militares", porque o propósito do Jango era exatamente isso. Como o Jango não tinha nada a ver com a revolução, digo eu, ele foi andando, andando, não resistiu, não resistiu, e quando não tinha mais nada no Brasil, passou para o Uruguai, pronto, acabou. E disse: "arrumem-se", não teve nenhuma atitude. Quer dizer, os militares só declaram vaga a sede da República quando o Jango está no Uruguai, não declaram antes. Agora, os militares, havia dois tipos de militares: uns que queriam o poder a todo custo, outros que queriam apenas mudar o sistema. O Golbery [do Couto e Silva], por exemplo, queria fazer a vontade dos americanos, um golpe que não fosse tão violento, talvez o Geisel também estivesse nisso. Mas havia outros que queriam dar uma rabecada de forró na coisa, que eram mais brutais, que era aquele de Minas Gerais, o cara que estava em São Paulo. Ou seja, aqueles mais clarividentes. Os militares queriam apenas mudar o poder e assumi-lo, mas não daquela forma que foi assumida, tanto que eles ficaram titubeando pra cá e pra lá etc. Depois tiveram de aceitar aquilo, tanto que eles puseram o Golbery de parter. Quem promoveu a general o Castello Branco foi o Jango. Depois vieram outros caras que eram uns trogloditas, como o Geisel, e não eram pelo golpe como foi dado, pois já tinham tentado dar um golpe antes.

\section{Diego Pacheco e Tiago João José Alves: Sua passagem por Santa Catarina foi marcante. Como foi seu percurso pelo Estado catarinense antes do golpe? \\ Alípio de Freitas: Foi tranquila. Eu não conhecia o Wright, eu pertencia} ao secretariado da Frente de Mobilização Popular (FMP), então o [Paulo] Schilling, que era o presidente da Frente, disse-me assim: "conhece esse senhor aí?", nos apresentou e perguntou: "você não quer ir para Santa Catarina, fazer a publicidade da frente?". Porque o Wright nem sequer era do PTB, era do Partido do Adhemar [de Barros] [Partido Social Progressista], porque o PTB não lhe deu legenda. Eu que estava sempre disponível, fui com ele para Santa Catarina e ele tinha muitos conhecimentos na área dos mineiros, sobretudo dos pescadores. Fizemos lá um esquema e andamos a fazer comícios nesses lugares. Uns saiam melhor que os outros porque não havia, assim, nenhum tipo de oposição grave. Outros saiam com mais dificuldade porque havia uma 
certa oposição. Santa Catarina tinha suas posições bem radicais. No entanto, nessa altura, fui recebido pelo presidente do PSD [Partido Social Democrático], pelo vice-presidente do PTB. O Paulo Wright é que teve alguns problemas, porque eles achavam que o Paulo era um traidor, não sei o que. Mas de grave mesmo, teve um cinema que o pessoal, as freiras, encheram aquilo de crianças do colégio pra nos encurralar lá dentro, mas não conseguiram fazer. Gritavam quando era o Wright, deixavam o prefeito falar, eram contra o Wright. Em Santa Catarina, na região dos pescadores, fomos muito bem recebidos, eles gostavam muito do Paulo. Acho que no cômputo geral, a estadia em Santa Catarina foi boa. Eu já voltei a Santa Catarina depois disso, já estive lá a fazer palestras na universidade, no liceu e não teve nada de mais.

Diego Pacheco e Tiago João José Alves: Nesse momento que o senhor fez esses comícios com o Wright, qual era a relação de vocês com o Partido Comunista em Santa Catarina? Havia esse contato?

Alípio de Freitas: Olha, não lhe posso dizer porque eu não conhecia o pessoal do Partido Comunista em Santa Catarina, provavelmente havia contatos. Da parte da gente de esquerda não houve nenhuma hostilização, então, provavelmente, as relações eram boas. As minhas relações com o Partido Comunista, a nível nacional, digamos, não eram boas, não eram fraternais, mas eram, digamos, boas no sentido de que não existia hostilização de parte a parte. Agora em Santa Catarina não posso dizer, porque aquilo foi tão rápido. Com o Paulo deviam ser melhores, porque o Paulo morava lá, ficava lá. Eu sei que na Assembleia [Legislativa], por exemplo, ele fez um discurso, ele foi aplaudido por todo mundo, quando eu estava lá, eu estava na Assembleia. Ele foi aplaudido por todo mundo, não teve ninguém que não o aplaudisse.

Diego Pacheco e Tiago João José Alves: O Paulo Schilling, que fez seu contato com o Paulo Wright, era próximo dos grupos brizolistas, o senhor tinha contato com esses grupos e com o próprio Leonel Brizola?

Alípio de Freitas: Tinha, sim, sim. E com o próprio Brizola. Inclusive o Brizola queria que eu fosse organizador dos Grupos dos Onze, mas como não tinha tempo, lhe disse que era melhor outra pessoa, depois ele nomeou outro cara que era realmente um organizador. Porque não tinha tempo nem pra me coçar, imagina pra estar a organizar. Chegaram a ser 11 mil grupos, eu não tinha tempo, imagina pra ficar numa secretaria a tomar nota disso e tal. O negócio dos Grupos dos Onze, a ideia quem a teve, até hoje não se fala nisso, foi o Betinho e o Aldo. Um dia eles foram à casa do Brizola almoçar, e eu estava lá, e eles vieram com a história de que no Brasil o povo gosta de futebol, que os times têm 11 jogadores, e que, portanto, 11 seria um número mítico para as pessoas. E que, portanto, 11, seria um número mítico para organizar grupos de onze amigos que não vão jogar bola, mas vão fazer política. E foi o Aldo, estou bem certo 
disso, foi na casa do Brizola, foram os dois que levaram a ideia para o Brizola. O Brizola apanhou logo a ideia e depois disse: "você pode ficar nisso?" e eu disse que não tinha tempo para ficar nisso. Era uma boa ideia, inclusive [o Grupo dos Onze], mas era preciso ter depois uma mobilização disso. Teve até uma mobilização na Rádio Mayrink Veiga, mas depois aquilo não teve sustentação política mais. Porque há muitas coisas que duraram enquanto durou o Brizola. Eu sempre defendi a ideia que o Brizola não devia ter ido embora, que o Brizola era útil no Brasil. Mas como a maioria queria ir embora, escapar-se, queria sair dali, Neiva [Moreira] e essa gente toda, queriam sair dali. Porque estavam num cagaço, porque eles não tinham prestígio nenhum ali, então pressionaram o Brizola para sair. Se o Brizola estivesse no Rio Grande do Sul quando foi o golpe, não haveria o golpe, porque todos os generais do RS estavam com o Brizola. Mas o Brizola, primeiro vacilou ficando no Rio de Janeiro, e depois, quando saiu do Rio, já saiu tarde, porque os generais não podem ficar a vida toda num lugar à espera que um sujeito se decida. O Crisanto [de Figueiredo], essa gente toda, estava tudo de armas na mão. O próprio [Amaury] Kruel, que era compadre do Jango, ficou à espera pra que o Brizola desse a ordem pra que ele pudesse avançar sobre o Rio. O coronel Dagoberto Rodrigues [chefe do Departamento de Correios e Telégrafos] fomos os últimos dois a sair da sala de reuniões, que era nos Correios, fomos e eu ele, porque já não havia mais ninguém em lugar algum. Então o Dagoberto me disse assim: "olha, eu vou embora e vou para a embaixada, e você deves ir pra embaixada, porque se eles te pegam, eles te fazem em pedacinhos". E eu nem fui logo. Dagoberto, acho que foi para o Uruguai. Mas era assim, todo mundo se mandou. O golpe foi fácil porque abriram as portas ao golpe. No Rio de Janeiro, ainda fui à Aeronáutica, o brigadeiro [Francisco] Teixeira, falei com ele, estava mais bêbado que um "cacho", não falava coisa nenhuma.

Ele tinha falado que o Jango, eu não sei se o Jango disse pra não levantar, por isso eu acho que o Jango não estava a crer no golpe. O outro brigadeiro também não quis levantar sem ordem do Jango. Então ficou tudo nisso. O [Almirante] Aragão, eu fui apanhar ele nos fuzileiros, eu fui pessoalmente, e disse: "como é que é?". Ele mandou reunir os fuzileiros, eram uns 300, e viemos a pé do quartel dos fuzileiros para a frente do palácio do [Carlos] Lacerda. E ele disse: "bombardeamos o palácio do Lacerda, não vai ficar pedra sobre pedra e acaba o golpe." Estavam já apontados, os fuzileiros em ordem, tudo, e aí vem da casa do Jango, das Laranjeiras, dois ou três oficiais, não recordo, a dar ordem do Jango para nos retirarmos. Alguns fuzileiros se recusaram a tirar as peças, mas saíram todos a chorar, porque eles sabiam o que ia acontecer. Era a turma da Associação dos Marinheiros e Fuzileiros Navais, que esses realmente iam fazer fogo e aí destruiriam aquilo tudo. E eu disse: “Aragão, vamos combater aquilo, mesmo sem ordem do Jango, porque você vai decidir, você tem força, e quando voltar, você não é ninguém”. E um dia, já depois da Anistia, eu já estava 
no Uruguai, encontrei o Aragão, ali em frente ao Teatro Municipal, e disse: “então, Aragão, recorda das palavras que lhe disse?". E ele disse: "recordo, mas as palavras não voltam atrás, era o que devia ter feito, não fiz e agora só me resta a chorar". Foram todos uns cagões. E na guerra: ou ages na hora ou não ages mais. Foi assim, isso eu sei, estava lá no lugar...

No princípio, o pessoal estava tão confiante que a revolução ia por diante, que isso era apenas um golpe do Jango, e até parecia que era. O PC, por exemplo, achava que o golpe duraria 6 meses, no máximo. Ninguém acreditava que aquele golpe fosse mais que 3 meses, 6 meses, porque o que era costume no Brasil: os generais davam os seus golpes, arrumavam as suas coisas e depois entregavam o poder os civis, de acordo com os interesses que eles tinham. Só que daquela vez não era assim, eles vieram pra ficar, pra mudar o regime, porque essa era a exigência das forças que participaram do golpe. E o PCdoB sempre disse que o golpe não durava mais de 6 meses, por isso, não entrou na luta contra o golpe. Os seus filiados entraram, alguns morreram, e outros, como Marighella, foi preso, foi solto, e depois rompeu com o Partido, mas isso era atribuído mais como descuido deles. A massa, a base estava com vontade. No Rio de Janeiro a publicação que fizeram contra o golpe foi atravessar a linha de ferro Leopoldina para não deixar passar nada para o porto, não teve outra atividade depois. Quando viram começar a prender os seus militantes, e outras organizações organizarem-se, aí perceberam que o golpe era sério. Que não era o Costa e Silvo, que aquilo era o Golbery, que era o chefe de Estado Maior, e que era o homem que vinha representar o Estado Maior dos EUA, era o sujeito que sabia exatamente o que queria. Além do mais, havia a pressão das forças armadas, da igreja, da grande burguesia, dos EUA, que dispuseram-se pra avançar, jogaram para área porta-aviões para que no caso de resistência, eles atuarem contra essa resistência. Talvez os objetivos deles não fossem muito claros. Por exemplo, o Miguel Arraes e as Ligas Camponesas achavam que eram o alvo principal, mas não eram. As Ligas podiam ser o alvo principal, mas o Arraes ainda controlou seu poder, controlou sua vontade de não entregar o poder, resistiria, na verdade, mas não era uma força capaz de ir mais adiante do que isso. As Ligas, como eram menos comandadas, porque era aparentemente um comando, mas não, era um comando na boca do Francisco Julião. As Ligas Camponesas era uma forma de organização dos camponeses, para organizá-los era preciso mantê-los em movimento, dar-lhes tarefas, ele sabia, mas as Ligas não teriam condições. Havia dois focos na Bahia, dois focos em Goiás, havia no Paraná, mas sem comunicação entre si e sem força. Eu, pessoalmente, que conhecia bem a situação, era secretário da FMP, sabia que havia os grupos de Onze, mas sem armas, não se faz revoluções. Quem tem mais armas, quem é mais capaz do ponto de vista militar, se tem uma direção correta, é quem ganha a guerra. Ali não havia nem direção correta, nem armas, porque o Brizola, de quem eu fui amigo até o último dia, apesar de discordar dele em muitas coisas, 
era um homem profundamente voluntarioso, capaz de acreditar naquilo que ele mesmo sonhava. Ele sonhava que se podia fazer uma revolução e já achava que ela já estava na rua. Era um homem de grande mobilização, era capaz de mobilizar gente, generais, e outras coisas parecidas, por lealdade, e as pessoas que estavam com ele eram leais, leais mesmo. Não era assim de estar com ele hoje e amanhã adeus que vou-me embora. Não era assim, era gente leal. E depois foi para o Rio Grande do Sul, quer dizer, um dos erros do Brizola foi esse, eu, por exemplo, fui contra, pois sabia que no Rio Grande do Sul ele não tinha nada a fazer, tinha dois generais, mas o comando das tropas estava em São Paulo... O Brizola quis repetir a Campanha da Legalidade, essas coisas não se repetem. O tempo passa, o Jango não toma nenhuma decisão, até que se exila, e os golpistas vão tomando decisões. Vão mandando prender, mandando fazer isso e aquilo, e você sabe como é o soldado: ele obedece quem manda. O Jango foi-se embora com todos os comandos obedecendo a ele... Com Kruel obedecendo, com o comandante do Terceiro Exército obedecendo a ele mesmo, os sargentos estavam todos com Jango, com a Marinha obedecendolhe, os fuzileiros obedecendo-lhe. Ele foi-se embora com toda a obediência do Exército, da Marinha e da Aeronáutica. Eu sempre achei que o Jango, não digo que estivesse com o golpe, mas tinha na manga outra coisa [Carta enviada ao Congresso citada acima]. Dessa altura em diante, as relações do Jango com o Congresso foram muito más, sempre, mais ainda, o Jango não voltou ao Congresso, ele ficou ressabiado por não terem lhes concedido poderes totais, porque ele achou que tinha sido traído. Porque ele queria ter poderes totais. $\mathrm{Na}$ hora em que ele pôde tirar sua vingançazinha, tirou, deixou que os militares tomassem conta.

Diego Pacheco e Tiago João José Alves: O senhor manteve contato com ativistas da causa independentista africana e antisalazarista. Como por exemplo: Fernando Albuquerque Mourão, José Maria Nunes Pereira, Filomena Ramos da Cruz, José Lima de Azevedo, José Manuel Gonçalves, Fidelis Cabral, entre outros. Como foi sua relação com eles? Chegou a ajuda-los no Brasil? Podes falar sobre a luta pela independência nas colônias portuguesas em África?

Alípio de Freitas: Esses moraram todos comigo. O José Lima de Azevedo morou comigo, foi meu secretário durante muito tempo, mais de 1 ano, morava na mesma casa que eu. Eles juntavam-se mais em São Paulo do que no Rio de Janeiro. No Rio tinham o apoio da UNE. Mas a atividade deles não era muita porque o Ministério dos Negócios Estrangeiros de Portugal e o Ministério do Brasil não facilitava a vida deles, porque o Brasil sempre apoiou Portugal na luta contra os povos da África. O José Manuel também esteve a morar comigo no Rio, mas depois que casou morava mais em Belo Horizonte. Agora era mais ativo que os outros, ele fazia conferência, fazia bate-papos e esse não 
era sequer angolano, era português nascido em Angola, mas era muito ativo. O Fidélis Cabral não tive grande relação com ele.

Diego Pacheco e Tiago João José Alves: Depois do golpe civil-militar, muitos desses militantes foram presos pela ditadura brasileira, incluindo Fernando Costa Andrade, José Lima de Azevedo, Fidelis Cabral, José Maria Nunes Pereira. O senhor pode nos dar sua opinião sobre isso? E na esteira dessas prisões, a UNE foi acusada de elaborar um plano comunista para Angola, planejado por centralmente por Marcos Jaimovitch e Anita Prestes. O que pensas disso?

Alípio de Freitas: Não fiquei preso com eles, porque eles os puseram em outros lugares. Os líderes africanos foram presos em São Paulo e no Rio de Janeiro, foram presos pelas diversas polícias. E não havia ainda um controle objetivo das lideranças políticas, não havia uma organização. A organização política no Brasil vira-se para os estrangeiros já quando pareceu que não havia mais brasileiros pra prender. E depois acontece que os líderes políticos de outros países ficaram um pouco amedrontados, e tinham razão, é claro. Não eram brasileiros, estavam metidos numa revolução que não era exatamente a deles, a oposição que tinha desapareceu, que era a UNE, pessoas eventuais etc. E aí ficaram assim mais ou menos ao Deus dará, esconderam-se aqui, esconderamse ali, ficaram em casa, e foram sendo buscados aqui e ali, onde é que eles foram encontrados. Estávamos sinalizados pela nossa atividade, a polícia caiu em cima de nós. Muitos foram para as embaixadas, outros não foram, mas ninguém pensou em dar asilo a outros enquanto as suas barbas estavam a arder. A prisão deles não se deu em função deles serem angolanos, guineenses deuse em função da política de Portugal e do Brasil em relação à luta dos países africanos. Acho que esse foi o motivo. No Brasil eles circulavam normalmente, eles andavam muito pela UNE, diga-se de passagem, a UNE sempre os apoiou, outros trabalhavam no Estadão de São Paulo. E nunca foram hostilizados por ninguém, a esquerda sempre os apoiou, andavam pela UNE, pelo Estado de S. Paulo, andavam lá por casa. Não tiveram hostilidade de ninguém, ninguém os hostilizou. Agora, os problemas que surgiam eram entre eles mesmos por qualquer uma razão, como surgem agora. Mas ajudas de fora, também não conheço que tivessem, eles estavam sempre sem dinheiro, mas eles eram muito ativos. Nas reuniões que existiam eles estavam sempre lá, fossem reuniões de partidos, de organizações, eles tinham comportamento militante em relação aos seus países. Não eram militantes fuleiros, era gente séria, gente que sabia que estava ali e porque estava ali e tudo que podiam fazer pela sua causa, faziam, nisso não tenho nenhuma dúvida. E sobre esse plano, acho que isso é treta.

Diego Pacheco e Tiago João José Alves: Nessa altura, a Polícia Internacional e de Defesa do Estado (PIDE) possuía agentes que seguiam os passos de 
oposicionistas africanos e portugueses. Pedro da Silveira, por exemplo, foi um desses "bufos", agente que vigiava esses ativistas no Brasil, a serviço do Estado Novo português. Inclusive ele acompanhou os passos do senhor. Provavelmente ele forneceu informações sobre às polícias brasileiras. $O$ que tens a dizer sobre isso? Até que ponto a PIDE colaborou com os órgãos de inteligência do Brasil?

Alípio de Freitas: Eu não sei se colaborou. Sei que logo depois da tomada do poder pelos militares, veio um grupo de policiais do Brasil fazer um curso na PIDE. Eu me recordo disso porque escrevi uma carta a um amigo dizendo o seguinte: "é engraçado, esses sujeitos durante anos torturaram, ainda tem necessidade de ir a Portugal aprender aquilo que já praticavam aqui". Agora, que havia gente infiltrada, havia.

Tinha um, por exemplo, os africanos andavam sempre muito sem dinheiro, como eles paravam muito por minha casa, às vezes ele fazia assim: "sabe, fulano, tens muitos amigos, talvez consiga um dinheiro pra eles", eu dizia que não tinha um banco para ajudá-los. Isso acontecia frequentemente, mas frequentemente eu ajudava com dinheiro para os exilados portugueses e africanos. Depois eu fui para a Embaixada, fiquem sem ter contato com portugueses, africanos, qualquer coisa no sentido. Mas enquanto vivia a minha vida normal, muitas vezes, não me recordo o nome desse sujeito, quem sabe é o Jaime, e ia-me lá, não era a pedir. Ia para dizer: "ih, os portugueses coitados, estão mal de dinheiro, não tem trabalho, veja lá se dá pra dar uma ajudinha, que esses portugueses aí, porque os salazaristas são porretas, desde que não se diga que é para antisalazaristas, eles até dão". Até que depois eles mesmos [portugueses e africanos] descobriram o sujeito, e ele fica lá no Brasil, esse era da PIDE. Eu estava tão metido na história da revolução no Brasil, que muitas coisas me passavam a leste. $\mathrm{O}$ fato de eu não saber praticamente nada da revolução portuguesa era isso, pra mim a revolução brasileira era o fundamental, era naquilo que eu estava metido e naquilo que eu militava. Lá falavam, “olha aí, tem alguma coisa aí, é preciso ter cuidado e tal", e que eu, pessoalmente, tomasse a iniciativa de procurar ou de saber, mas não, porque não era realmente o meu interesse.

Diego Pacheco e Tiago João José Alves: Durante a sua prisão, houve alguém da PIDE envolvido?

Alípio de Freitas: Não, durante a minha prisão eles esqueceram-me.

Diego Pacheco e Tiago João José Alves: Gostaríamos de retomar um assunto, o senhor poderia falar um pouco sobreo desaparecimento do Wright?

Alípio de Freitas: Eu o conheci quase que fortuitamente, era secretário da FMP, o secretário-geral era o Schilling. Eu estava ainda como diretor das Ligas Camponesas, mas num processo de rompimento com o Julião. Fui para o Acre, 
para a Amazônia, estava mais ligado, naquela altura, à Ação Popular. Quando voltei de Manaus, estava o Wright lá na secretaria, aí diz-me o Schilling: "já se conhecem? Pois é, o Wright é deputado de SC, um grande companheiro", fez elogio, e o Wright assim bem humildemente: "não, eu colaboro, sou deputado, mas podia ser outro". Depois o Wright me perguntou se eu estava ocupado com alguma tarefa, e eu disse: "que eu saiba não", mas o Schilling deve saber, e disse: "não, até agora não, pois fosse o caso de ir pra Santa Catarina, que é um negócio bem difícil pra nós, pra nós a prioridade é SC." Fui pra casa, meti umas roupas numa maleta e disse: "pronto, Wright, então amanhã a gente vai". O Schilling deu algum dinheiro e viajamos para SC. Vou à casa do Wright, conheço a mulher dele, os filhos dele, que eram pequenos, e estivemos a conversar. Fizemos um plano de trabalho para SC. E ele dizia assim: "aqui é meio perigoso, vamos ver como há de ser". Nas tarefas, também estivemos na rádio, foi lá que tomei o microfone do radialista que só falava mal de nós.

\section{Diego Pacheco e Tiago João José Alves: E depois do golpe, qual foi seu contato com Wright em Santa Catarina?}

Alípio de Freitas: Depois do golpe, o Wright andou por lá, sobretudo na zona de pescadores. Eu também fui a essa zona de pescadores e de mineiros, pois tinha um acerto com eles pra me guardarem um tanto de dinamite, se caso nós tivéssemos partido pra outra que não foi aquela. $\mathrm{O}$ Wright também estava nisso. E fui lá ainda umas tantas vezes e estava tudo acertado, eram valentes aqueles pescadores e aqueles mineiros, e cumpridores. Depois não passei mais lá.

$\mathrm{O}$ pessoal de SC tomou consciência que foi absolutamente injusto com o Wright, porque o Wright foi nesses últimos anos a maior figura naquele Estado. Ele sacrificou a vida dele, não deixou 1 minuto da vida dele, a não ser pra lutar por SC, o pensamento dele ia pra SC. Mas, mesmo assim, eles foram injustos com ele, até a igreja dele expulsou-o, ele depois até fez um discurso numa universidade sobre esse assunto, acho que foi grave, eles readmitiram-no novamente. Até disseram que andava sempre engravatado, o Wright andava sempre muito bem arrumado, mas de gravata era difícil vê-lo. Depois fui ver os filhos onde é que eles moram agora. Eu gostava muito dele, estive com ele Cuba, achava um companheiro excelente, daqueles companheiros que pode até discordar de ti, deixava o que tinha de dizer, depois, mansamente, punha o problema de novo e aí chegava-se a um acerto, mas não por imposição. Com aquela grandeza toda do corpo, ele tinha a capacidade de usar aquilo com mansidão, isso via nas atuações dele com as outras organizações. Todos o respeitavam até por isso. Ele não brigava. Estive com ele na Assembléia Legislativa, ele fez um discurso muito tranquilo. Ele era homem de grandeza. E depois SC tinha percebido que ele era uma pessoa especial, muito especial. E agora que estou a falar dele, estou com muita saudade dele, porque eu sou um choramingas. Eu gosto dos meus amigos e sou capaz de chorar por eles, 
porque eu os amo. E o Wright foi um desses. O Wright era uma pessoa singular. Há pessoas que pra quem a política não é o lugar correto. Talvez não fosse o lugar correto pra ele a política, ainda que ele fosse um homem que ia atrás da política, ia atrás das coisas, sabia dizer as coisas. Ele era muito firme nas coisas que dizia, as pessoas ouviam e sentiam-no. Quando ele foi reintegrado, eu fiz um discurso violentíssimo contra a igreja e ele jamais faria isso. Machucoume tanto alguém como ele ser expulso da igreja dele, que ele amava. Porque o Wright foi um sujeito que viveu a sua igreja em plenitude. Não era um sujeito que era protestante porque o pai era. Pra ele, a igreja era uma forma de estar presente na vida, na luta, na religião, na raça pelos pobres. Não era uma forma de ser deputado, era uma forma de estar na vida pelos outros, não tirou proveito disso nenhum, nem tirava. Isso é muito importante.

\section{Diego Pacheco e Tiago João José Alves: Como foi a passagem de vocês em Cuba?}

Alípio de Freitas: Bem, quando fomos pra Cuba, o Wright foi conosco, fomos num grupo, ele tinha muitos conhecimentos em Cuba e haviam outros companheiros que iam pra Cuba também. Em Cuba tínhamos conhecimentos até em nível de Ministério, tínhamos alguns amigos em vários níveis. O Wright aprendia rápido e com muito interesse, a faceta principal dele era organizar as coisas, pois num grupo de 20 homens, uns se conhecem, os outros nem se conhecem, uns fazem amizades, outros nem fazem amizades. Manter o grupo unido, porque alguns já estavam fartos e queriam ir embora, e os cubanos não mandavam ninguém embora. Começava um treinamento, se quisesse ir embora podia ir, mas ia numa quinta trabalhar: colher batatas ou qualquer outra coisa, mas não iam embora para cidade. Era difícil manter um grupo assim, às vezes dava briga etc. Eu mesmo tive um problema com um sujeito que queria sair, veio perguntar a mim, achando que eu era o chefe e diz: "eu quero sair", e eu disse: "não é a mim que tens de pedir, tem que falar com o comandante fulano", e ele me diz: "já falei com ele, já disse que tenho ficar aqui ou ir para um campo de trabalho, mas não quero ir a um campo de trabalho". [Alípio] "Então tens de ficar aqui e ficar aqui que tens de cumprir todas as normas, é o que tem de ser". E ele disse "isso é pra vocês que são todos uns fascistas ou qualquer coisa assim". Ele estava com um caixote na mão com feijões, dei-lhe um chute e esparramou aqueles feijões todos e ainda disse para apanhá-los. Apanha sim, se não te dou-lhe um tiro, e puxei assim a arma. E ele falava, falava. Aí veio o Wright e diz “o que tem esse?". [Alípio] "Não tem nada, está apanhando esses feijões" e contei a história a todo mundo.

\section{Diego Pacheco e Tiago João José Alves: Como era o treinamento?}

Alípio de Freitas: Era duríssimo. Os comandos daqui eram brincadeira. Às 6 da manhã já estava de pé, já estava a correr, a correr, depois tomava café, 
continuavas a correr. Depois aprendia a usar a arma, fazia o treinamento de armas, estavas com um treinador, aprendia a usá-la, quando usá-la. Enquanto não soubesses tudo isso de olhos fechados, não passavas adiante. Era assim. Tinha um descanso de vez em quando, mas no mato. Tínhamos uma rede, onde tirávamos uma soneca, ajudávamos os camponeses a fazer coisas, de vez em quando. Nós estávamos no campo. Havia lugares onde os camponeses já sabiam daquilo, então diziam: "você sabe fazer o que? Sabe plantar batatas? Então vai ajudar aquele camponês a plantar batatas". Não era nada fácil, durava quase 1 ano aquilo, era difícil.

\section{Tiago João José Alves: Como foi seu contato com Portugal pós-1974?}

Alípio de Freitas: Nenhum ou quase nenhum. Aqui ninguém sabia que eu estava participando de uma revolução noutro país. Só soube-se aqui e ali, ou houve alguma promoção disso por uns companheiros, mas a sério mesmo só se soube quando o Zeca Afonso fez aquela canção [se chama "Alípio de Freitas"]. Por outro lado, nós no Brasil também não sabíamos nada o que estava a acontecer em Portugal. Nada, quer dizer, ouvimos o Grândola Vila Morena no dia 25 de Abril. Havia um sujeito que tinha aqueles radiozinhos de uma só pilha, o único que existia, e ouviu o Jornal do Brasil dizer assim: "em Portugal há uma revolução" e a gente mandou calar logo. Ouvíamos as notícias às $7 \mathrm{~h}$, ao meio dia, e às $17 \mathrm{~h} 30,18 \mathrm{~h}$, mais nada. Não tínhamos mais nenhuma informação sobre isso porque suspenderam as visitas. Não havia ali informação de jornal, não havia nada. Passamos a ter mais notícias quando fomos transferidos, passado um tempo, por causa de uma greve de fome, para Ilha Grande, nós estávamos, nessa altura, na Fortaleza de Santa Cruz. Não tínhamos assim muita ideia, a ideia que tínhamos é que tinha sido uma revolução de esquerda, nunca achamos que era uma revolução de direita. Depois fomos acompanhando pela televisão. Um dia escrevi uma carta que mandei pelo Ruy Guerra, que era um cineasta meu amigo, foi para Portugal e entregou-a lá não sei a quem, nem ele sabe. A carta bateu na mão do Zeca e o Zeca fez essa cantiga, a carta a tenho hoje. Fez essa cantiga, aqui em Portugal a cantiga já se cantava, mas lá no Brasil não. Um dia, um amigo meu, que era da Marinha e era da Embaixada, levou alguns jornais e uma fita cassete que tinha essa cantiga e é a primeira vez que ouço isso. Bem, fiquei chocadíssimo, depois levei-a para outros ouvirem e ficaram igualmente chocados pela cantiga e porque, digamos, tínhamos a certeza de que havia alguém no mundo que pensava em nós. Que o pior que tem nessas coisas é tu estar no fundo da prisão e teres certeza de que ninguém está pensando em ti. Depois vim a Portugal, encontrar o Zeca, encontramo-nos e viramos grandes amigos, irmãos, pronto, foi isso a partir daí.

Diego Pacheco e Tiago João José Alves: No final da década de 1970, o Leonel Brizola veio a Portugal para tentar reorganizar o trabalhismo 
brasileiro, o senhor teve contato com o grupo dele ou com essas pessoas que o ajudaram a reorganizar o PTB?

Alípio de Freitas: Eu sabia que eles estavam, eu fui sempre ligado ao Brizola, fomos até amigos. Mas ele estava interessado em fundar o Partido e ser da Internacional Socialista. Não era o Alípio de Freitas que lhe estava a interessar. Ninguém fez nada por mim. Eu sei que falaram nisso, mas o que disseram foi "é muito difícil, não vamos nos meter nisso". Um dia falei disso com o Brizola e ele me disse: "é, não foi bem assim, mas era difícil". E eu disse: "era difícil sendo comigo, sendo com você não era difícil". As pessoas que se interessaram aqui por mim eram portuguesas.

Diego Pacheco e Tiago João José Alves: No momento de reabertura no Brasil o senhor se envolveu em alguma atividade política?

Alípio de Freitas: Teve uma altura em que a ditadura brasileira fez um processo contra mim, logo que houve a revolução aqui, de expulsão. Mas como ninguém daqui respondeu, ninguém pediu a expulsão, fiquei lá. Sai da prisão apátrida até hoje. Ainda tento um pouco com o PTB, mas não me cheirava bem a coisa, porque todos os caras que eu conheci na luta, os piores e os melhores, estavam metidos no PTB. E eu disse, bom, com essa gente eu não quero nada. Preferi ir à luta armada, me enganei um pouco, pouco não, muito. Alguns tinham sido traidores mesmo nos seus experimentos, eu não estava pra isso.

Diego Pacheco e Tiago João José Alves: E a sua passagem pela África? Alípio de Freitas: Fiquei um tempo sem trabalho, depois vim aqui a Portugal, depois voltei pra lá [Brasil], vendia camisas, vendia coisas na praça, fiquei um pouco camelô. Trabalhava um pouco no jornal Tribuna da Imprensa, e um dia estava na Embaixada brasileira, está lá um amigo meu e disse-me assim: "quer ir para Moçambique trabalhar com camponeses já amanhã?!” Pronto, fui para Moçambique. Em Moçambique passei dois anos e tal, foi um tempo formidável realmente. Depois que saí da prisão, politicamente foi o melhor tempo da minha vida. Depois vim, fui para televisão, vim para o Alentejo, e aqui estou aí.

Diego Pacheco e Tiago João José Alves: Como o senhor vê a crise brasileira atual? Como o senhor avaliar os governos do Partido dos Trabalhadores? Qual a saída política para o país?

Alípio de Freitas: Já tive várias opiniões sobre o Brasil, várias, bastantes e já sofri bastante pelo Brasil atual. Até porque não foi isso que o Lula prometeu às pessoas. $\mathrm{O}$ Lula deixou-se enredar pelos mesmos que foram os donos do Brasil. Quando o Lula nomeia para Ministro um homem do George Soros, que é o maior financista do mundo, disse: "pronto, adeus, não há mais nada a fazer". Nomeou, foi a moeda de troca: "nós não criamos problemas ao 
Brasil se nomeiam o fulano que é o meu secretário". E aí adiante, a coisa foi de mal a pior. E depois o Lula nunca soube fugir aos compromissos que existiram sempre na vida brasileira. Porque a vida brasileira sempre houve compromissos com A e com B, o Estado tinha compromissos com A, A tinha compromissos com o Estado. Depois todo mundo devia, ninguém pagava, os problemas fundamentais nunca se resolveram, nem os da escola, nem os da saúde, nem os do trabalho porque eles tocavam sempre no fundamental do Brasil que é a estrutura do Brasil. O Brasil é um país cuja estrutura assenta na estrutura feudal, o Brasil, fundamentalmente, é um país feudal. Quer dizer, o latifundiário é um senhor feudal, o industrial é um senhor feudal. É um país capitalista, mas cujo capitalismo é feudal. O que acontece, acontece que isso é avesso ao desenvolvimento. Podemos ter uma grande fábrica de automóveis, sim, mas quem manobra essa grande fábrica? Ou é um grupo estrangeiro, ou é um grupo nacional, mas que não é dos interesses do Brasil, é de outro interesse qualquer e trata os trabalhadores como escravos. Um trabalhador nos EUA não é tratado como no Brasil. Por isso, o ensino é medíocre. O Lula ainda tentou fazer escolas etc. Mas não adianta fazer escolas. A escola precisa de mestres que te digam alguma coisa, que te digam aquilo que aprendes serve de pouco ou de quase nada, porque vais ser um trabalhador de uma empresa que vai te explorar a vida toda. Vai te dar um dinheiro para sobreviver, mas vai te explorar sempre. $\mathrm{O}$ dono de escravos também fazia isso. Ele dava-te comida, mas explorava-te a vida toda, até morrer, isso que era o feudalismo. E nunca te dava alguma liberdade. Quer dizer, qual é a liberdade de um trabalhador no Brasil? Votar? De escravo passou a votar num saco, os votos já eram contados, agora é exatamente a mesma coisa. O sujeito vota, o sujeito já sabe quantos votos tem. Pode ser até numa igreja é mais fácil, quantos clientes tem a igreja? Cinquenta? Então tem 50 votos. Há mil formas de te escravizarem. E como a educação não existe, como a educação está fora de todos os planos, então o Brasil há de sempre ser sempre isto, há de ser sempre dependente do capital, a não ser que se rompa com esse sistema. E depois, tem mais o seguinte, a dependência externa, porque não é só a dependência interna. Tu, no Brasil, tem o Banco nacional, a quem pede dinheiro, a quem tens de pagar e pagas como? Pagas com o rendimento que tiras do seu escravo e depois mantém ele na miséria. Mantém na miséria social, moral, não tem transporte, como antigamente. A sociedade escravocrata, no fim da escravatura, que diferenças fundamentais existe? Não existe nenhuma. Há um sujeito que pode fazer uma maravilha, mas quando ele morrer, está tudo deixado. Por exemplo, o Getúlio Vargas fez segurança social, pronto, morreu, foi praticamente tudo para o beleléu. Porque aquilo não estava enquadrado dentro da cultura brasileira. Por que é que os hospitais faliram, por que a segurança brasileira faliu? Tudo porque aquilo não se enquadra, aquilo não tem enquadramento cultural. Eu, como crente naquele país, acho, acho não, vou fazer tudo o possível para muda-lo, mas não tenho 
certeza que muda nada, não tenho certeza que muda nada, nada. Isso eu digo aos meus amigos que não tenho a certeza de nada, não tenho a certeza que mude nada. Daqui a 50 anos seremos isto, ou somos agora, e haverá festas, tudo que há agora, mas seremos talvez campões do mundo de futebol, mais nada, mais nada...

Diego Pacheco e Tiago João José Alves: Alípio, podemos usar essa entrevista nas nossas pesquisas e de repente publicar numa revista?

Alípio de Freitas: Pode fazer o que quiser, até jogar no lixo se quiser...

Notas de Fim

1 Para saber mais sobre Alípio de Freitas, ver: DE FREITAS, Alípio. Resistir é Preciso: memórias do tempo da morte civil no Brasil. Rio de Janeiro: Record, 1981.

2 FREITAS, Alípio. Paulo Wright: amigo maior que o pensamento. In: GOMEZ, Iur; SOARES, Regina Maura (org.). Notas de um Desaparecido: Paulo Stuart Wright: O tempo, o sujeito e o mundo. Florianópolis: [S.n.], 2014, p. 191.

Entrevista recebida em julho de 2017. Aceita em agosto de 2017. 